\title{
Expression of Simian Retrovirus Type D Serotype 2 Envelope in Insect Cell Using Baculovirus Expression Vector System
}

\author{
UUS SAEPULOH ${ }^{1}$, DIAH ISKANDRIATI ${ }^{1}$, \\ MOHAMAD SADIKIN ${ }^{2}$, AND JOKO PAMUNGKAS ${ }^{1,3}$ \\ ${ }^{1}$ Primate Research Center, Institut Pertanian Bogor, Jalan Lodaya II/5, Bogor 16151, Indonesia; \\ ${ }^{2}$ Department Biochemistry and Molecular Biology, Faculty of Medicine, Universitas Indonesia; \\ Jalan Salemba Raya 6, Jakarta 10430, Indonesia; \\ ${ }^{3}$ Faculty of Veterinary Medicine, Institut Pertanian Bogor, Darmaga Campus, Bogor 16680, Indonesia
}

\begin{abstract}
Simian retrovirus type-D (SRV) is a causative agent of simian acquired immunodeficiency syndrome in Asian macaques, and can serve as a viral model in understanding of retrovirus infection because of some similarities to human AIDS pathogenesis. Study of infection and pathogenesis of SRV in macaques could be a strategy of vaccine and antiviral development for preventive and therapeutic purposes. We expressed the SRV-2 envelope gene using baculovirus expression vector system and transfected it to Spodoptera frugiferda insect cell line for SRV-2 recombinant protein production. Analysis using PCR and sequencing technique of recombinant in the passage-3 viral stock indicated the occurrence of recombination between SRV-2 envelope and baculovirus genome. Purification using immobilized metal ion affinity chromatography $\mathrm{Ni}^{2+}$-NTA to recombinant protein could minimize the presence non-specific proteins. The SDS-PAGE analysis showed a specific protein for SRV-2 gp70 envelope. Western blot analysis of this purified protein indicated a specific reaction with anti-SRV-2 antibody positive of Macaca fascicularis serum shown as SRV-2 gp70 envelope band.
\end{abstract}

Keywords: SRV-2, baculovirus, Sf9 cell, Macaca fascicularis

The simian retrovirus (SRV) is a Betaretrovirus capable of causing an AIDS-like disease in Asian macaques. Of the five simian retrovirus neutralization serotypes identified (SRV-1 to SRV-5), three (SRV-1 to SRV-3) have been molecularly cloned and genomically sequenced (Daniel et al. 1984; Marx et al. 1984; Gardner et al. 1988). Disease caused by the more commonly found SRV-2 infection in macaque is characterized by diarrhea, chronic weight loss, anemia and sometimes retroperitoneal fibromatotis (Moazed and Thouless 1993). SRVs have emerged as significant pathogens in captive macaques following recognition of their etiologic role in outbreaks of immunodeficiency disease at several Regional Primate Research Centers in the US in early 1980 (Daniel et al. 1984; Gardner et al. 1988).

Serological studies in Macaca fascicularis, Macaca nemestrina and Pongo pygmeus in Indonesia showed the presence of antibodies to SRV-2, leading to the assumption that these animals have been infected with SRV or similar agent (Iskandriati et al. 1998a; Iskandriati et al. 1998b; Warren et al. 1998). The high prevalence of disease among wild populations pose some problems for breeders providing a population of SRV-free macaques, since macaques are frequently used in biomedical researches (Lerche and Osborn 2003). Regarding potentially active infection and immune abnormality affected by this virus, SRV-2 is a pathogenic agent that should be eliminated in the Macaca breeding colony (Marx et al. 1984; Lerche et al.1995; Morton et al. 2008).

In this study, we developed SRV-2 envelope (Env) recombinant protein production method using baculovirus expression vector system (BEVS). This recombinant protein could be used as antigen sources for serological test against antibody anti-SRV-2 or as SRV-2 recombinant protein vaccine candidate. Recombinant baculoviruses are widely used to

*Corresponding author, Phone: +62-251-8347519,

Fax: +62-251-8310033, E-mail: uussaepuloh@yahoo.com express heterologous genes in insect cells. The BEVS has some advantages, such as the capacity for large inserts of DNA and high yield of recombinant protein. Protein produced in BEVS is very similar to naturally occurring human proteins in terms of post-translational modifications, biological activity and protein stability (Possee 1997; Joshi et al. 2000). For this reason, BEVS is widely used in academia and industry for expression of a variety of recombinant protein in insect cells (Kost and Condreay 1999).

\section{MATERIALS AND METHODS}

Determination of Entry Clone SRV-2 Env. The SRV-2 provirus isolated from peripheral blood mononuclear cells (PBMCs) of Indonesian M. fascicularis (provided by PSSP LPPM IPB) was PCR amplified using specific primers SRV-2 BacNTerm 5823U to SRV-2 LTR90L that produced the blunt end PCR product. This PCR product was cloned to $\mathrm{pENTR/}$ $\mathrm{D} / \mathrm{TOPO}$ vector (Invitrogen), which facilitated the entry into baculovirus genome. The plasmid pENTR/D/TOPO was then analyzed using sequencing methods with specific primers (SRV Mf-Mn 5737-LTR: 216U20, 727U20, 1284U20 and 1770U20).

Spodoptera frugiferda (Sf9) Insect Cell Preparation. Sf9 cells were seeded into a six-well plate $\left(8 \times 10^{5}\right.$ cells/well) in $2 \mathrm{~mL}$ of complete Grace's insect medium (GIBCO) supplemented with $10 \%$ FBS (fetal bovine serum), $100 \mathrm{U} \mathrm{mL}^{-1}$ Penicillin, and $100 \mu \mathrm{g} \mathrm{mL} \mathrm{mL}^{-1}$ Streptomycin. The cells were incubated at $27^{\circ} \mathrm{C}$ for one hour to allow the cells fully attach to the bottom of the plate and then were verified by inspecting them under an inverted microscope.

LR Recombination. The LR recombination reaction was prepared by adding $\mathrm{pENTR/D/TOPO} \mathrm{plasmid} \mathrm{as} \mathrm{entry} \mathrm{clone}$ (100-300 ng), BaculoDirect linear DNA (300 ng), 5x LR clonase reaction buffer, TE buffer and LR clonase enzyme mix. The mixture was incubated at $25^{\circ} \mathrm{C}$ for one hour, then added with 
$2 \mathrm{~mL}$ of protease $\mathrm{K}$ solution and incubated for $10 \mathrm{~min}$ at $37^{\circ} \mathrm{C}$. LR recombination reaction and cellfectin (Invitrogen) reagent were combined in $800 \mathrm{~mL}$ Grace's insect medium unsupplemented to make the transfection mix. The medium in the cells was removed and added to the entire tranfection mix dropwise onto the cells, then incubated at $27^{\circ} \mathrm{C}$ for $5 \mathrm{~h}$. The transfection mixture was later on removed and added with $2 \mathrm{~mL}$ of complete growth medium with antibiotics and $100 \mathrm{uM}$ ganciclovir to each well. The plate was incubated at $27^{\circ} \mathrm{C}$ for $96 \mathrm{~h}$ and visual inspection of the cells was daily conducted to observe signs of the infections using inverted microscope. Once the transfected cells demonstrated signs of infection, the medium was collected from each well and transferred to a sterile snap cap tube. This was used as the P1 viral stock, kept at $4{ }^{\circ} \mathrm{C}$ and protected from light. The recombination reaction was performed according to standard procedure by Invitrogen.

High-Titer Viral Stock Preparation. The Sf9 cells at density $8 \times 10^{5}$ cells per well was seeded in $2 \mathrm{~mL}$ of complete growth medium with $100 \mathrm{mM}$ ganciclovir in a six-well tissue culture plate. The cells were incubated at $27^{\circ} \mathrm{C}$ for $72 \mathrm{~h}$, then the medium was collected and centrifuged at $1000 \mathrm{x} \mathrm{g}$ (Beckman GS-6R) for 5 minutes. The supernatant is P2 viral stock and kept at $4{ }^{\circ} \mathrm{C}$. To generate the high titer viral stock $\mathrm{P} 3$, the Sf9 cells was seeded at density $8 \times 10^{5}$ cells $\mathrm{mL}^{-1}$ in $20 \mathrm{~mL}$ growth medium in T75 flask. Cells was incubated in $27^{\circ} \mathrm{C}$ for $48 \mathrm{~h}$ then infected with $0.5 \mathrm{~mL}$ P2 viral stock and incubation was continued for $72 \mathrm{~h}$. The supernatant was collected as P3 viral stock.

PCR and Sequencing Analysis of P3 Viral Stock DNA Recombinant. DNA was isolated both of supernatant and cells P3 viral stock using QiaAmp DNA Minikit procedure (QIAGEN). DNA recombination between BaculoDirect N-Term and SRV-2 Env was amplified using polyhedrin forward primer and SRV-2 Env 5974L and 6243L. PCR product was purified using Qiagen Gel Extraction kit (Qiagen, USA) and cloned into pCR 2.1 TOPO 10 (Invitrogen, USA). Nucleotide sequence was carried out on automatic DNA sequencing (ABI, USA) and alignment of the obtained sequences was performed with computer software BLAST program (NCBI).

Recombinant Protein Purification. Sf9 cells were grown in T225 flask to a density of $8 \times 10^{5}$ cells $\mathrm{mL}^{-1}$ and infected with P3 viral stock. Media were harvested at $72 \mathrm{~h}$ post-infection and centrifuged at $528 \mathrm{x}$ g for $10 \mathrm{~min}$ at $4^{\circ} \mathrm{C}$ (Beckman GS-6R). The collected supernatant were concentrated by tangential flow filtration with Pellicon XL device (Millipore) then centrifuged at $191000 \mathrm{x}$ g for $3 \mathrm{~h}$ at $4{ }^{\circ} \mathrm{C}$ (Beckman XL90 Optima, fixed angel Ti90). The pellet were diluted in $1 \mathrm{~mL}$ PBS and loaded onto a $2 \mathrm{~mL}$ Probond chelating column (Invitrogen) charged with nicel-nitriloacetic acid $\left(\mathrm{Ni}^{2+}-\mathrm{NTA}\right)$ and equilibrated with native binding buffer. After washing the column with $8 \mathrm{~mL}$ native washing buffer supplemented with $20 \mathrm{mM}$ imidazole, recombinant protein were eluted with elution buffer containing $250 \mathrm{mM}$ imidazole. Fractions were collected in $2 \mathrm{~mL}$ and the protein concentrations were analyzed by bicincroninic assay kit (Pierce). The $\mathrm{Ni}^{2+}$-NTA purification procedure was referred to Probond purification system from Invitrogen.
SDS-PAGE and Western Blot Analysis. The purified SRV-2 Env recombinant protein was detected by electrophoresis on a ready gel $4-15 \%$ gradient Tris-HCl SDSPAGE (Biorad) and then either stained in a gel with Coomassie blue or transferred onto a nitrocellulose membrane. The membrane was rinsed with PBST $0.1 \%$, blocked with BLOTTO (5\% skim milk in PBST $0.1 \%$ ) for $2 \mathrm{~h}$ at room temperature and cut into strips. Individual strips were incubated with M. fascicularis plasma/serum containing primary antibody anti-SRV-2 diluted in BLOTTO for overnight. After being washed three times with PBST $0.1 \%$, the membrane was incubated with anti-human IgG alkaline phosphatase conjugate (1:5000 dilution in BLOTTO). The membrane was washed and the bands were developed by reaction with 5bromo-4-chloro-3-indolyl phosphate and nitro blue tetrazolium (BCIP-NBT) as substrate.

\section{RESULT}

The SRV-2 Env provirus was isolated from PBMCs of Indonesian $M$. fascicularis using specific primer SRV-2 BacNTerm 5823U (upper primer) and SRV-2 LTR90L (lower primer) with $P f u$ polymerase enzyme, resulting in blunt PCR product about $2000 \mathrm{bp}$ (Fig 1).

In order to facilitate the insertion of the gene of interest SRV-2 Env to baculovirus vector, we used pENTR/D/TOPO cloning kit (Invitrogen) as entry clone. This entry clone utilized a highly efficient method to clone a blunt end PCR product directly into a baculovirus vector with no additional ligation or restriction enzyme required. In this system, PCR products are directionally cloned by adding four bases to the forward primer (CACC). The overhang in the cloning vector (GTGG) invades the 5'end of the PCR product, anneals to the added bases and stabilized the PCR product in the correct orientation (Fig 2).

Sequencing to the $\mathrm{pENTR/D/TOPO} \mathrm{plasmid} \mathrm{was} \mathrm{done}$ using M13 forward primer and some specific SRV-2 Env primers (216U20, 727U20, 1284U20, 1770U20). Analysis of the sequencing result with nucleotide alignment using BLAST program indicated the presence of the gene of interest SRV-2 Env in pENTR/D/TOPO plasmid with proper orientation (data not shown). This plasmid was then recombined to

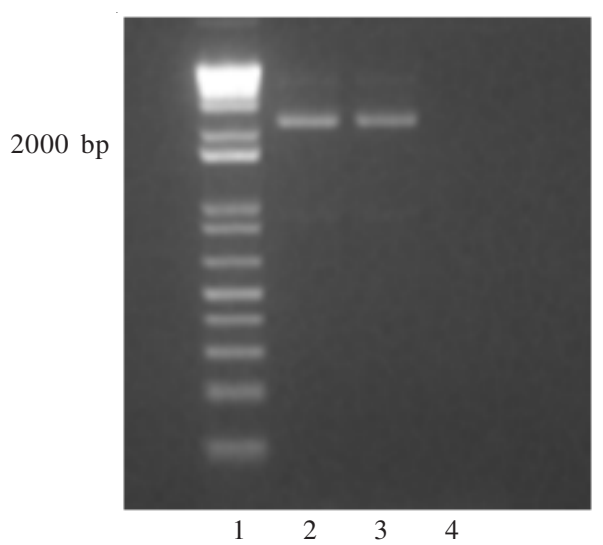

Fig 1 Amplification of SRV-2 Env provirus isolated from Indonesian Macaca fascicularis using specific primer BacNTerm 5823U-LTR90L. 1, $1 \mathrm{kbp}$ DNA ladder (Invitrogen); 2-3, PBMCs cell; 4, Reagent control. 


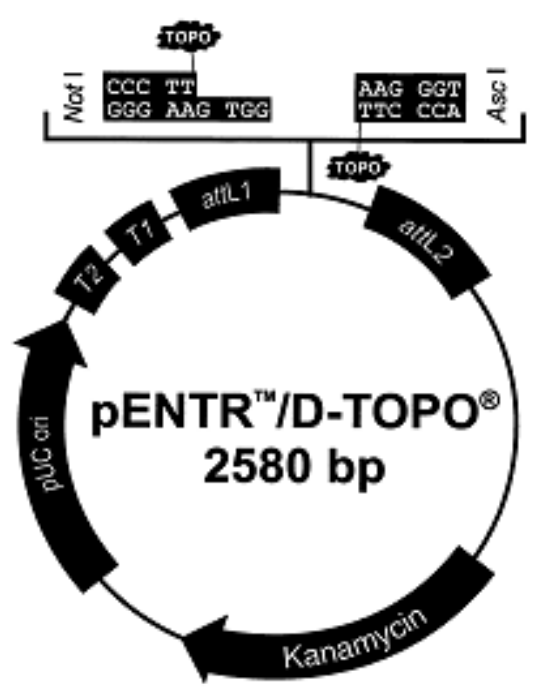

Fig 2 Schematic diagram of pENTR/D/TOPO that will facilitated the SRV-2 Env as entry clone to baculovirus genome.

baculovirus genome using LR recombination reaction with LR clonase enzyme mix. In this case, we used linear BaculoDirect Baculovirus Expression System (Fig 3) containing the entry clone to transfect onto the Sf9 cells using cellfectin cationic-lipid, $\mathrm{N}, \mathrm{N}^{\mathrm{I}}, \mathrm{N}^{\mathrm{II}}, \mathrm{N}^{\mathrm{III}}$-tetrametyl$\mathrm{N}, \mathrm{N}^{\mathrm{I}}, \mathrm{N}^{\mathrm{II}}, \mathrm{N}^{\mathrm{III}}$-tetrapalmitylspermine (TM-TPS) with dioleoyl phosphatidylethanolamine (DOPE).

The SRV-2 Env gene recombinant was expressed using polyhedrin promoter and proliferated in Sf9 cells. Negative selection of the recombinant with correct expression was done using ganciclovir. Infection of the Sf9 cells typically displayed the specific characteristic of cell morphology as observed from visual inspection using inverted phase microscope. Characteristics of infected cells were shown with increased cell diameter, cessation of cell growth, detachment and cell lysis.

In order to verify the recombination between SRV-2 Env with baculovirus genome in Sf9 cells, we amplified the passage-3 (P3) viral stock using PCR technique with specific primer of polyhedrin forward to SRV-2 5974L and SRV-2 6243L. The specific bands about $400 \mathrm{bp}$ and $600 \mathrm{bp}$ was indicated the presence of recombination between SRV-2 Env and baculovirus genome (Fig 4). Additionally, to ensure the recombination of SRV-2 Env with baculovirus genome, the PCR product then cloned to pCR 2.1 TA TOPO cloning kits (Invitrogen), and the plasmid was then sequenced using M13 forward primer. Analysis of the sequencing result indicated the presence of recombination between SRV-2 Env and baculovirus genome in correct direction (data not shown).

The SRV-2 Env recombinant protein expression was demonstrated by specific bands for envelope glycoprotein (gp70) and gp20 on SDS-PAGE analysis, although there were

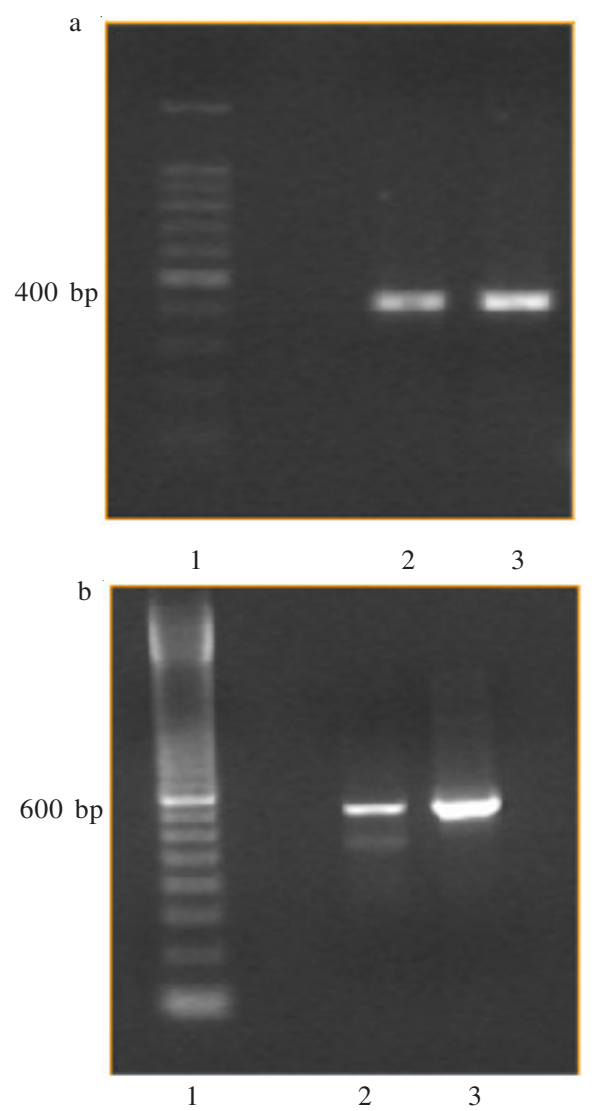

Fig 4 PCR analysis of P3 viral stock of supernatant and pellet cells using specific primer: panel a, primer polyhedrin forward to SRV2 Env 5974L and panel b, primer polyhedrin forward to SRV-2 Env 6243L. 1, 100 bp DNA ladder (Invitrogen); 2, supernatant cell; 3, pellet cell.

some non specific bands (Fig 5). The purification to the viral stock using affinity chromatography purification system containing metal chelating resin $\mathrm{Ni}^{2+}$-NTA was minimizing the presence of non-specific protein, specifically designed to purify $6 \mathrm{xHis}$-tagged protein. It was shown by SDS-PAGE analysis with the specific band of SRV-2 gp70 Env (Fig 6). Western blot analysis of this purified protein indicated a specific reaction with anti-SRV-2 antibody positive of $M$. fascicularis serum shown by SRV-2 gp70 Env band (Fig 7).

\section{DISCUSSION}

The gene of interest to be expressed using baculovirus vector is SRV-2 Env isolated from Indonesian M. fascicularis. This gene will be expressed to surface glycoprotein and transmembrane that will first be recognized by host receptor in the initial infection (Brody et al. 1994; Rasko et al. 1999). This SRV-2 Env protein is very stable suggesting high degree of adaptation of SRV-2 to its host (Staheli et al. 2006).

We used pENTR Directional TOPO cloning kit (Invitrogen) that facilitated the recombination of SRV-2 Env gene to

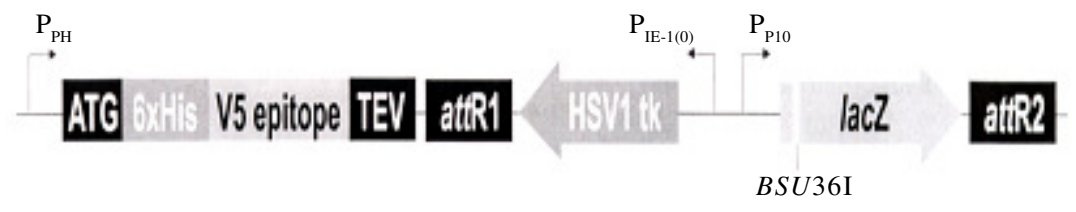

Fig 3 Schematic diagram of genetic linear DNA baculoDirect N-term. 


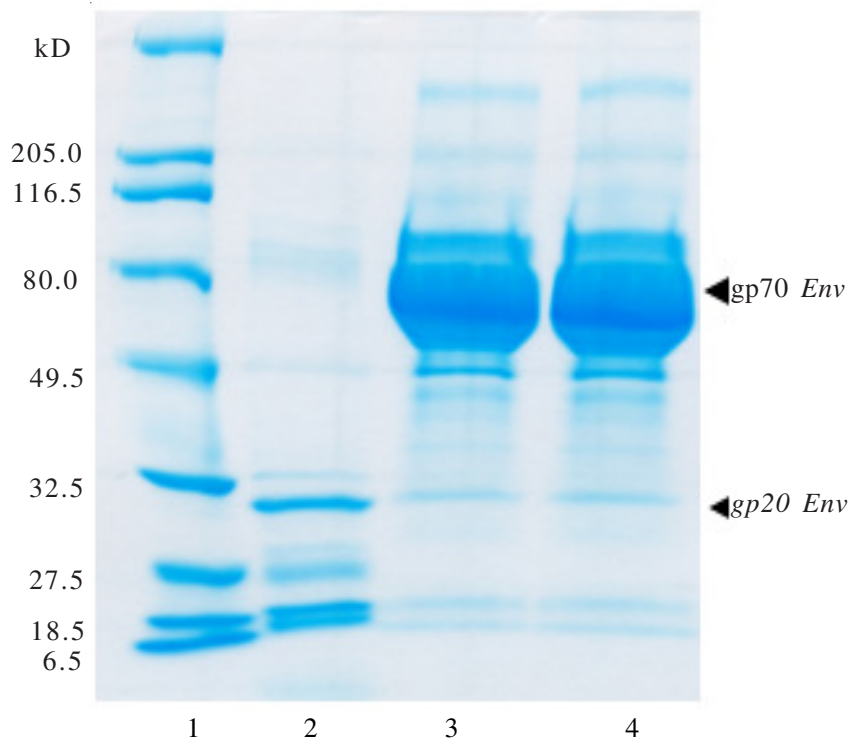

Fig 5 Expression of SRV-2 Env recombinant protein using SDS-PAGE technique. 1, broad low marker protein standar; 2 , whole SRV-2 Antigen; 3, supernatant cell P3 viral stock; 4, pellet cell P3 viral stock

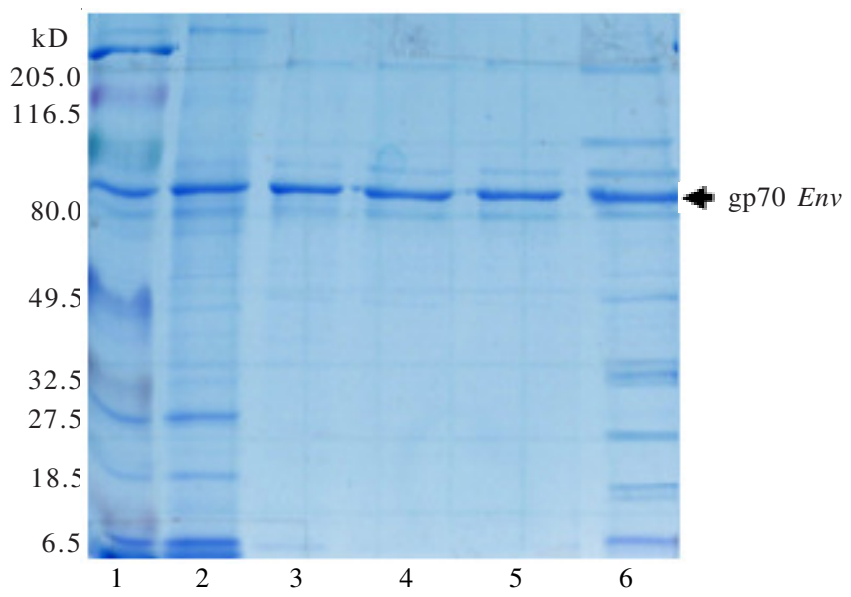

Fig $6 \mathrm{Ni}^{2+}$-NTA purification analysis of SRV-2 Env recombinant protein in P3 viral stock by SDS-PAGE staining with Coomassie brilliant blue. 1, protein standard broad low marker; 2, whole SRV-2 antigen virus; 3 , elution buffer fraction; 4, washing buffer fraction; 5, binding buffer fraction; 6, recombinant protein pre-purification. baculovirus genome. This is a universal cloning method using the site-specific recombination properties of bacteriophage lambda (Landy 1989). BaculoDirect has evolved from gateway technology (Invitrogen, USA) platform and enables the direct transfer of the gene into a baculovirus genome without the need for the propagation of the recombinant bacmid DNA. Briefly, attR1 and attR2 gateway sites have been introduced into the viral genome to enable the recombinatorial cloning of gene interest from the gateway entry clone directly into baculovirus DNA. This feature make BaculoDirect system ideal for protein expression system, since it immediately removes one of the more-time consuming stages of the entire process (Hunt 2005).

The specially engineered BaculoDirect linear DNA (Fig 3 ) contains a strong polyhedrin promoter $\left(\mathrm{P}_{\mathrm{PH}}\right)$ for high level protein expression. Att recombination sites for efficient recombination with any attL-flanked gateway entry vector and herpes simplex virus thymidine kinase (HSV-1 TK) and LacZ genes located between $a t t R$ sites for the selection of recombinant bavaculovirus. During the LR reaction with gateway entry clone, the $L a c Z$ and $T K$ genes are recombined out as by-products. Sf9 cells are then placed under selection with ganciclovir [9-(1,3-dihydroxy-2-propoxymethyl) guanine], which is enzymatically phosphorylated by HSV-1 $T K$. Once phosphorilated, the active analog incorporates into DNA and inhibits DNA replication. Ganciclovir selection has been used in Sf9 cell to purify the recombinant viruses, therefore eliminating any remaining parental non-recombinant virus (Hunt 2005).

We observed the SRV-2 Env expression both in pellet and in supernatant cells indicated by specific bands of gp70 and gp20 after SDS-PAGE analysis (Fig 5). It means that the recombinant protein has already been released to the cell supernatant. In this study, we used the full-length gene of SRV-2 Env, and the presence of gp20 band indicated that the SRV-2 Env protein has been cleaved by cellular protease enzyme, although the band was thinner compared to whole SRV-2 antigen (Brody et al. 1994). It was assumed that to produce both gp70 and gp20 recombinant protein the use of full-length SRV-2 Env protein was not efficient. The expression level of full-length Env protein was lower compared to truncated Env protein (Yao et al. 2000).

b
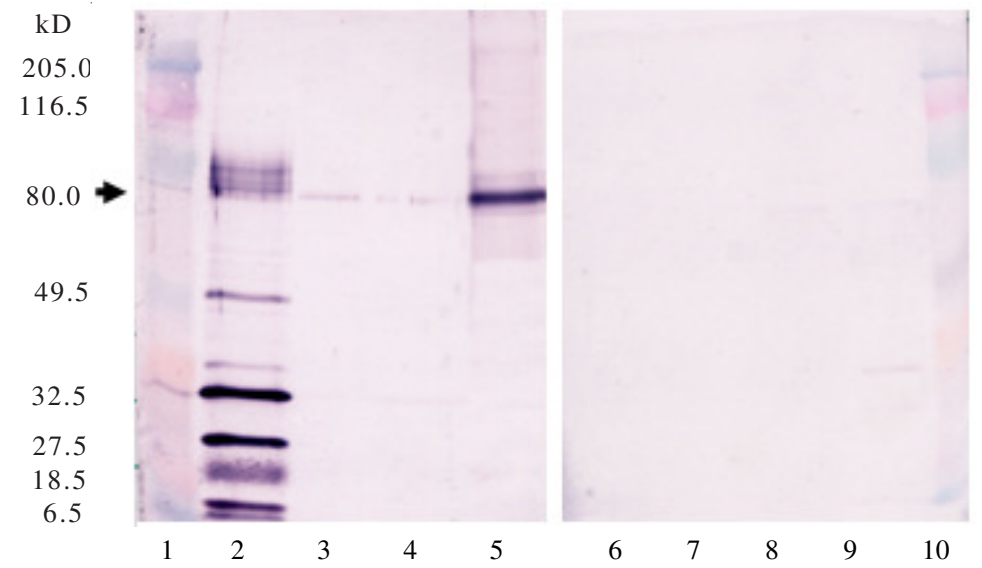

Fig 7 Western blot analysis of $\mathrm{Ni}^{2+}$-NTA purified SRV-2 Env recombinant protein probed with positive antibody anti-SRV-2 of $M$. fascicularis serum (a) and negative antibody anti-SRV-2 of $M$. fascicularis serum (b). 1, 10, kaleidoscope protein standard; 2, 9, SRV-2 antigen virus; 3, 8, binding buffer fraction; 4, 7, washing buffer fraction; 5, 6, elution buffer fraction. 
The recombinant protein was purified using immobilized metal ion affinity chromatography (IMAC) containing metal chelating resin $\mathrm{Ni}^{2+}$-NTA to bind the $6 x$ His-tagged protein. This His-tagged protein will compete with imidazole and will be removed from the column when the concentration was increased to $250 \mathrm{mM}$ in elution buffer. This purification system has already removed some non-specific proteins, shown by elution buffer fraction in SDS-PAGE analysis (Fig 6). We could not observe the gp20 Env protein, probably it was also removed during the early elution process due to its low level protein expression.

In this study, we observed the antigenicity of this purified SRV-2 Env recombinant protein on western blot analysis using antibody anti-SRV-2 positive of $M$. fascicularis serum. It was shown by a specific band of SRV-2 gp70 Env (Fig 7). Thereby, this gp70 Env recombinant protein retained its antigenicity and could be used as alternative antigen source for serological test in EIA (enzyme immunosorbant assay) or western blot analysis against antibody SRV-2 and could be applied for routine diagnostic purposes in supporting the Macaca Specific Pathogen Free (SPF) colony program. In the future, the development of SRV-2 recombinant protein will substitute the use of SRV-2 active viral protein as antigen source due to its pathogenicity and biosafety level requirement.

\section{REFERENCES}

Brody BA, Rhee SS, Hunter E. 1994. Post-assembly cleavage of retroviral glycoprotein cytoplasmic domain removes a necessary fusion activity. J Virol 68:4620-7.

Daniel MD, King NW, Letvin NL, Hunt RD, Seghal PK, Desrosiers RC. 1984. A new type D retrovirus isolated from macaques with an immunodeficiency syndrome. Science 223:602-5.

Gardner MB, Luciw P, Lerche N, Marx P. 1988. Nonhuman primate retrovirus isolates and AIDS. Adv Vet Sci Comp Med 32:171-90.

Joshi L, Davis TR, Mattu TS, Rudd PM, Dwek RA, Shuler ML, Wood HA. 2000. Influence of baculovirus-host cell interactions on complex N-linked glycosilation of a recombinant human protein. Biotechnol Prog 16:650-6.
Hunt I. 2005. From gene to protein: a review of new and enabling technologies for multi-parallel protein expression. Protein Expr Purif 40:1-22.

Iskandriati D, Pamungkas J, Suparto IH, Grant R, Agy MB, Morton WR, Sajuthi D. 1998a. Evidence for retroviruses infection in captive Orangutans (Pongo pygmeus) returned to Indonesia. J Med Primatol 27:173-80.

Iskandriati D, Pamungkas J, Surya M, Mariya S, Budiarsa IN, Sajuthi D. 1998b. Prevalensi antibodi Simian Retrovirus tipe-D serotipe-2 (SRV-2) pada Macaca fascicularis dan Macaca nemestrina di empat propinsi di Indonesia. JPI 2:5-8.

Kost TA, Condreay JP. 1999. Recombinant baculovirus as expression vectors for insect cells and mammalian cells. Curr Opinion Biotechnol 10:428-33.

Landy A. 1989. Dynamic, structural, and regulatory aspect of sitespecific recombination. Annu Rev Biochem 58:913-49.

Lerche NW, Heneine W, Kaplan JE, Spira T, Yee JL, Khabbaz RF. 1995. An expanded search for human infection with simian type D retrovirus. AIDS Res Hum Retrovir 11:527-9.

Lerche NW, Osborn KG. 2003. Simian retrovirus infection: potential confounding variables in primate toxicology studies. Toxicol Pathol 31:103-10.

Marx PA, Maul DH, Osborne KG. 1984. Simian AIDS: isolation of type D retrovirus and disease transmission. Science 223:1083-6.

Moazed TC, Thouless ME. 1993. Viral persistence of simian type-D retrovirus $(\mathrm{SRV}-2 / \mathrm{W})$ in naturally infected pigtailed macaques (Macaca nemestrina). J Med Primatol 22:382-9.

Morton WR, Agy MB, Capuano SV, Grant RF. 2008. Specific pathogen free macaques: definition, history and current production. ILAR J 49:137-44.

Possee RD. 1997. Baculovirus as expression vector. Curr Opin Biotechnol 8:569-72.

Rasko JJ, Battini JL, Gotischalk RJ, Mazo I, Miller AD. 1999. The RD114/simian type D retrovirus receptor is a neutral amino acid transporter. Proc Natl Acad Sci 96:2129-34.

Staheli JP, Marquardt T, Thouless ME, Bruce AG, Grant RF, Tsai CC, Rose TM. 2006. Genetic variability of the envelope gene of type D simian retrovirus-2 (SR-2) subtypes associated with SAIDSrelated retroperitoneal fibromatotis in different macaques species. J Virol 3:1-15.

Warren KS, Niphuis H, Heriyanto, Verschoor EJ, Swan RA, Heeney JL. 1998. Seroprevalence of specific viral infections in consfiscated orangutans (Pongo pygmaeus). J Med Primatol 27:33-7.

Yao Q, Kuhlmann FM, Eller R, Compans RW, Chen CY. 2000. Production and characterization of simian-human immunodeficiency virus-like particles. AIDS Res Hum Retrovir $16: 227-36$ 